\title{
A profissão docente representada por estagiários do curso de Letras
}

\section{Le métier d'enseignant représenté par des stagiaires $d u$ cours de Lettres}

Pollyanne Bicalho RIBEIRO (UFC) pollyanne_br@yahoo.com.br

Eliane Gouvêa LOUSADA (USP) elianelousada@uol.com.br

Recebido em: 27 de maio de 2018. Aceito em: 12 de set. de 2018.

\section{RIBEIRO, Pollyanne Bicalho; LOUSADA, Eliane Gouvêa. A profissão docente representada por estagiários do curso de Letras. Entrepalavras, Fortaleza, v. 8, n. 3, p. 40-62, out- dez/2018}

Resumo: O trabalho objetiva identificar representações sociais sobre o trabalho do professor sob a ótica do estagiário. A pesquisa se baseia nos fundamentos da Teoria das Representações Sociais (MOSCOVICI, 1989; JODELET, 1989), Teoria Dialógica do Discurso (BAKHTIN, 2003, 2004), Clínica da Atividade (CLOT, 1999, 2010, CLOT \& FAÏTA, 2000), e Ergonomia da Atividade (SAUJAT, 2004). Como corpus, recorremos a excertos de quatro encontros com estagiários, produzidos de duas formas: a) exposições de desenhos feitos por eles sobre a profissão docente; $b$ ) reações e discussões dos estagiários após a leitura de relatórios de estágio escritos por estudantes do ano anterior, cujas discussões foram fomentadas pela leitura de relatórios de estágio. Os resultados sinalizam, a partir das vozes mobilizadas, representações positivas sobre a profissão docente, apesar de modalizações que as relativizam, tendo em vista as adversidades expostas sobre o métier. Nas interações, atualizamse representações sobre a profissão docente que importam para a reflexão e reformulação da prática formativa.

Palavras-chave: Profissão Docente. Representações Sociais. Prática Formativa. 
Abstract: This study aims at identifying social representations about the work of the teacher from the perspective of the trainee. The research is based on the foundations of Theory of Social Representations (MOSCOVICI, 1989; JODELET, 1989), Dialogical Theory of Discourse (BAKHTIN, 2003, 2004), Clinic of Activity (CLOT, 1999, 2010, CLOT \& FAÏTA, 2000) and Ergonomics of Activity (SAUJAT, 2004). As a corpus, we used excerpts from four meetings with trainees, produced in two ways: a) exhibitions of drawings made by them about the teaching profession; b) reactions and discussions of the trainees after the reading of internship reports written by students from the previous year, whose discussions were fomented by the reading of traineeship reports. The results point out positive representations about the work of teaching, in spite of the modifications that relativize them, considering the adversities exposed on the métier. In the interactions, representations on the work of teaching that are important for the reflection and reformulation of the formative practice are updated.

Keywords: Work of Teaching. Social Representations. Formative Practice.

\section{Introdução}

Neste artigo, objetivamos identificar representações sociais sobre o trabalho do professor sob a ótica do estagiário. Nossa preocupação se volta, portanto, para a formação dos estagiários, futuros professores, que irão, em breve, assumir a sala de aula. Acreditamos que o estágio é um lugar de passagem para a mobilização de representações sobre a profissão que se escolheu atuar. Diante do quadro representacional apresentado, há oportunidade de reconhecermos maneiras de significar a docência e, ainda, abordarmos sentimentos de inseguranças, expectativas, frustrações que nos permitirão ajustar rotas metodológicas tomadas na formação, a fim de se ter um profissional mais preparado para a atividade de ensino.

O estágio pode cumprir a função de atenuar os efeitos do "choque de realidade" decorrente do rompimento com a universidade e ingresso efetivo nas escolas. Garcia (1999, p. 28) considera como choque de realidade "[...] o período de confrontação inicial do professor com as complexidades da situação profissional e as condições de permanência deste profissional na docência, apesar de todas as agruras que vivencia." Através da verbalização, do diálogo, podemos acessar as representações e, por conseguinte, lidar com as inquietações sobre o trabalho do professor, o que poderia contribuir para o desenvolvimento profissional (CLOT, 2010).

A pesquisa ${ }^{1}$ que deu origem a este artigo baseia-se em representações depreendidas de relatos e desenhos produzidos em quatro encontros com 05 estagiários do curso de Letras da UFC. Nos encontros, recorremos à leitura de quatro relatórios produzidos por

${ }^{1}$ O trabalho é fruto da pesquisa de pós-doutorado intitulada "Representações Identitárias do Professor no curso de Letras", realizada sob a supervisão da Profa. Dra. Eliane Lousada, na USP. 
v. 8 (3)

40-62

out-dez 2018

estagiários de semestres anteriores, visando fomentar discussão e reflexão sobre a profissão docente. Baseando-nos em Moscovici (1989), Jodelet (1989), acreditamos que as representações sociais são maneiras de compreender e explicar a realidade, que orientam as práticas e posturas dos seres sociais e, portanto, colaboram para o sentimento de pertença a um dado grupo social. Diante disso, procuramos delinear as representações construídas nos excertos de quatro encontros com estagiários, produzidos de duas formas: a) exposições de desenhos feitos por eles sobre a profissão docente; b) reações e discussões dos estagiários, sujeitos desta pesquisa, após a leitura de relatórios de estágio escritos por estudantes do ano anterior.

Defendemos que é preciso tematizar a profissão na prática formativa, somente assim podemos diminuir as lacunas, muitas vezes, descritas pelos próprios alunos, como verdadeiros abismos entre a formação e o exercício da profissão. As práticas de aprendizagem em contextos de formação profissional, como é o caso do estágio, devem se pautar em modelos decorrentes da prática e não elaborados para a prática, visto que os modelos para a prática são orientados por aquilo que se considera desejável do que por aquilo que efetivamente ocorre (SAUJAT, 2004, p. 17). A pesquisa foi profícua para motivar reflexões sobre a heterogeneidade, plasticidade e dinamicidade das representações construídas nos textos dos estagiários sobre os processos pelos (e nos) quais tais representações emergem e se (trans)formam, seja no plano coletivo, seja no plano individual.

\section{Dialogia e representações sobre o trabalho do professor}

O desenvolvimento profissional é um processo, não é algo linear, estático, os parâmetros, as variáveis, as representações são constantemente (re)avaliadas. Os profissionais se (trans)formam à medida que a relação com o trabalho, com os pares, com os recursos também se (trans)formam.

Os primeiros enfrentamentos na sala de aula podem revelar a complexidade e a imprevisibilidade, os conflitos do real, do trabalho. Essa experiência pode deixar transparecer os desacordos entre o que é da ordem do ideal e o que é da ordem da realidade, sendo que a atividade "subtraída, ocultada ou recuada nem por isso está ausente, mas influi, com todo o seu peso, na atividade presente" (CLOT, 2010, p. 104) Os dilemas da atividade devem ser reconhecidos para que se possa 
avançar, desenvolver profissionalmente. Para esse autor, é necessário levar em conta o real da atividade, ou seja, toda a atividade de trabalho, tanto o que se faz, quanto o que não se faz, o que não se quis fazer, o que se quis fazer mas foi impedido etc. (CLOT, 2010).

Nas trocas verbais, através das interações, há intercâmbio de ideias, de informações, de representações. As representações sociais são dinâmicas, dada a natureza do objeto sobre o qual são constituídas, e também relativas, ou seja, a elaboração representativa, em uma situação concreta, processa-se segundo os valores apreendidos por um determinado grupo social (MOSCOVICI, 1989). Dessa forma, cada qual representa o objeto da realidade de forma variada, relaciona-o a sua história, a sua formação e expõe essa representação no discurso.

Não obstante às especificidades individuais, há aspectos dessas representações que são comuns e colaboram para a composição do acervo de traços que permite identificar certo grupo social. Jodelet (1989, p. 36) define representação social como "uma forma de conhecimento, socialmente elaborado e compartilhado, tendo uma finalidade prática e concorrente à construção de uma realidade comum a um conjunto social." De acordo com essa premissa, a realidade é construída socialmente, daí pensar que os saberes são dependentes e implicados pelas representações mobilizadas pelos sujeitos sociais.

Jodelet (1989, p. 50) defende que a posição social ou sua função influenciam os conteúdos representacionais e sua estruturação e isso se deve à relação ideológica que mantém com o mundo social, por obedecerem às normas institucionais e aos modelos ideológicos. A análise dessa rede pode permitir uma efetiva compreensão das relações linguagem/trabalho estabelecidas nas instituições de ensino. Os estudos acerca de textos produzidos em situação de trabalho educacional podem colaborar para a compreensão do trabalho do professor tanto no seu agir concreto quanto em relação a alguns aspectos das representações que socialmente se constroem sobre eles (MACHADO, 2004, p. 135).

O discurso é que garantirá e conferirá plasticidade e dinamicidade aos modos de significar objetos do mundo, é a via de acesso às representações. Através das interações, o ser humano se apresenta para o outro e, nessa teia, desvela-se quem é um em detrimento do outro e, ainda, quem é um no complemento do outro. $\mathrm{Na}$ dimensão profissional, o profissional iniciante, muitas vezes, se baseia nas representações que construiu, nos modelos de outros profissionais, para orientar e justificar o seu agir. 
v. 8 (3)

40-62

out-dez

2018

O diálogo, no sentido mais amplo, não incluiria apenas os presentes - emissor/enunciador e receptor/destinatário - na interação, mas a diversidade de outros no projeto discursivo. Essa premissa é garantidora de toda e qualquer comunicação verbal, ou seja, a incorporação do outro nas palavras do eu revela o relativismo da produção individual. Todo e qualquer discurso produzido é uma construção de muitos através de um. Até mesmo o diálogo interno traz vozes de outrem que produzem efeitos (BAKHTIN/VOLOSCHINOV, 2004).

Quando um enunciado é posto, haverá sempre outro enunciado ao qual ele se relacionará, não há uma pretensa criação genuína, pura, a heterogeneidade é própria da linguagem, é algo constitutivo em decorrência do dialogismo. Sempre interagimos, mobilizando outros enunciados, ainda que não ditos, expressos, eles serão evocados para que haja compreensão (BAKHTIN/VOLOSCHINOV, 2004).

De acordo com Bakhtin (2003), a compreensão responsiva ativa é uma resposta do locutor ao interlocutor, que se engaja (em graus variados) no projeto comunicativo. A atitude responsiva é mais um desdobramento do dialogismo, visto que considera o outro na dinâmica discursiva.

A linguagem, portanto, é constitutiva desse sujeito aprendiz, como também responsável por sua transformação, pois "aquilo mesmo que torna o signo ideológico vivo e dinâmico faz dele um instrumento de refração e de deformação do ser." (BAKHTIN/VOLOSCHINOV, 2004, p.47). A palavra sempre carregará sentido ideológico em razão dos significados atribuídos por sujeitos nas interações.

Ressaltamos, ainda, que a palavra, carregada de significações, incorpora, ainda, as condições reais da comunicação verbal, o contexto de produção interfere sobremaneira na enunciação, haja vista que "o signo e a situação social em que se insere estão indissoluvelmente ligados. O signo não pode ser separado da situação social sem ver alterada sua natureza semiótica." (BAKHTIN/VOLOSCHINOV, 2004, p.62).

Nasinteraçõesverbais, ostrabalhadoressignificamsuasexperiências, constroem o acervo representacional do seu coletivo de trabalho, conferem capital simbólico para validar ou invalidar tomadas de posicionamentos em relação aos pares, à hierarquia, à organização institucional, à prescrição etc. Assim, a presença de ações convencionais, de determinados gestos característicos, do manuseio de certos instrumentos, de atos bem sucedidos ou não, de representações sobre o objeto do trabalho, das formas de se relacionar com os outros profissionais, dos deveres esperados, constituem o que Clot e Faïta (2000), inspirados pelo conceito de gênero discursivo postulado por Bakhtin (2003), definiram como gênero profissional. 
A compreensão do gênero discursivo pode subsistir a identificação da natureza do gênero, portanto, o seu funcionamento nas práticas sociais, aqui, particularmente, os seus efeitos para a prática formativa. Vale dizer que, por serem "tipos relativamente estáveis de enunciados" (BAKTHIN, 2003), os gêneros são mais ou menos plásticos, dinâmicos, criativos a depender da situação de produção.

Refletindo sobre a concepção de gênero no contexto profissional, Clot e Faïta (2000, p. 11) defendem que "se fosse preciso criar, todas as vezes que agimos, cada uma de nossas atividades, o trabalho se tornaria impossível". O gênero profissional consistiria nas "obrigações compartilhadas pelos que trabalham para conseguir trabalhar, frequentemente, apesar de todos os obstáculos e, às vezes, apesar da organização prescrita do trabalho" (CLOT, 2010, p.119).

Sem esse acervo comum sobre o trabalho, não haveria referência sobre o agir, o que reduziria o poder de ação do indivíduo, comprometendo a organização do trabalho. Os gêneros profissionais carregam significações, construídas ao longo da História, sobre o métier em questão, há uma função de registro, de memória, que, de certa forma, assegura, confere coerência ou não às escolhas do trabalhador.

Os gêneros, discursivos ou profissionais, estão submetidos às regras estabilizadas no contexto sócio-histórico, isto é, as ações podem ou não ser adequadas a determinado gênero. Essas regras, relativamente convencionais, podem ser, a qualquer momento, reinventadas, recriadas, para melhorar as condições do trabalho ou a sua eficiência. O "chão da fábrica", nos dizeres de Clot (2010), deve ser um lugar de luta para o aprimoramento do trabalho e do trabalhador.

Portanto, ainda que as normas genéricas tenham caráter coercitivo, há espaço para a singularidade na forma de exercer o seu trabalho. O conflito gerado pelo enfrentamento dos conhecimentos do grupo diante do meu conhecimento pode ser fecundo para a promoção de mudanças necessárias tanto na ordem intrapessoal, quanto interprofissional. O estilo, no contexto do gênero profissional, é justamente a impressão do indivíduo interposta na ação do coletivo, é a marca autoral no desenvolvimento do métier.

Béguin \& Clot (2004, p.43) afirmam que o métier

não é, certamente, apenas uma 'prática'. Também não é apenas uma atividade. Nem apenas uma profissão. Preferimos definilo como uma discordância criativa ou destrutiva entre as quatro instâncias em conflito de uma arquitetura fundamentalmente social. 
v. 8 (3)

40-62

out-dez

2018

O métier é "irredutivelmente pessoal, interpessoal, transpessoal e impessoal." (CLOT, 1999, p. 86)

Ogênero, portanto, cumpriria opapeldemediador entreo indivíduo, envolvido em seu trabalho, e as instâncias reguladoras, prescritivas, desse trabalho. É, "de algum modo, a parte subentendida da atividade daquilo que os trabalhadores de um determinado meio conhecem e veem, esperam e reconhecem, apreciam e temem" (CLOT \& FAITA, 2000, p. 11).

De acordo com a assertiva, o gênero profissional constitui maneiras de fazer e de agir, presentificadas no meio social, nas quais nos baseamos para o nosso agir. A entrada no métier pode ser um importante sinalizador sobre as respostas empreendidas por outros trabalhadores e, ainda, o que merece ser reparado, quais dispositivos, recursos, merecem ser ressignificados, reinventados, contribuindo, assim, para o desenvolvimento dos gestos do métier e, ao mesmo tempo, esclarecendo sobre o seu funcionamento (SAUJAT, 2004).

Voltando para o conceito de gênero discursivo, retomamos Bakhtin (2003) que afirma que, fundado no dialogismo, o discurso/ texto contempla o contexto verbal e o contexto extraverbal (aspectos situacionais, históricos, ideológicos), ou seja, ele revela o que é próprio da situação enunciativa concreta, como também elementos sociodiscursivos, estabilizados nas e pelas práticas comunicativas na História. O discurso/texto instancia a alternância de sujeitos no discurso e possibilita a mobilização da multiplicidade de vozes, muitas vezes, dissonantes, para o projeto do dizer.

O discurso/texto, portanto, é constitutivamente heterogêneo, atravessado por vozes diversas que produzem efeitos de sentido nas interações. Segundo Authier-Revuz (1990, p. 26), há dois tipos de heterogeneidade discursiva: a constitutiva, referindo-se "aos processos reais de constituição dum discurso" e a mostrada, referindo-se "aos processos de representação, num discurso, de sua constituição" (AUTHIERREVUZ, 1990, p.32). A heterogeneidade mostrada se constituiria pelas "formas linguísticas de representação de diferentes modos de negociação do sujeito falante com a heterogeneidade constitutiva do seu discurso." Para a autora, há três formas ou tipos de heterogeneidade mostrada: (i) o discurso relatado (no qual o locutor se vale de suas palavras para traduzir as palavras do outro) ou cita as próprias palavras do outro (discurso direto); ii) o locutor destaca as palavras do outro por meio de aspas, de itálico; (iii) o discurso do outro não é marcado, visto que se mostra no espaço do implícito como, por exemplo, o discurso indireto livre. 
Sobre a noção de vozes, Maingueneau (1996) expõe várias formas com as quais o locutor pode integrar uma enunciação numa outra enunciação, já que todo discurso/texto é fundado em um já dito. Segundo o autor, diversas são as formas de citar as vozes do outro: discurso citado direto, discurso citado indireto, discurso citado direto com "que", modalização em discurso segundo, ilhota citacional, resumo com citações, discurso indireto livre (MAINGUENEAU, 1996).

Na próxima seção, passaremos para a exposição da geração de dados e análise do corpus, a fim de compreendermos o acervo representacional sobre a profissão docente a partir das vozes mobilizadas no discurso do estagiário, visto que o enunciado, conforme explicitado, é atravessado por múltiplas vozes. O eco de vozes, marcadas ou não nos textos dos estagiários, cumpre funções diversificadas na construção de sentidos, conforme Boch e Grossmann (2002).

\section{o Contexto da pesquisa}

A fase exploratória da pesquisa abrangeu estagiários vinculados ao curso de Letras da UFC. Os estagiários, matriculados na disciplina Estágio de Regência em Ensino de Língua Portuguesa, disciplina oferecida no fim do curso $\left(7^{\circ}\right.$ ou $8^{\circ}$ período), devem cumprir em média 32 horas-aula preferencialmente nas escolas públicas de Fortaleza. Geralmente, as turmas são compostas por 16 alunos, tendo em vista que o professor, coordenador do estágio, deve acompanhar a atuação dos estagiários na escola.

Com a anuência da professora-coordenadora do estágio, expusemos a proposta da pesquisa para uma turma de Estágio de Regência em Ensino de Língua Portuguesa. A proposta consistia em quatro encontros realizados ao longo do semestre, durante duas horas, a fim de debatermos sobre a profissão docente. Tais encontros seriam subsidiados pela leitura de quatro relatórios elaborados no ano anterior por estagiários que concluíram a referida disciplina. Dos 16 alunos matriculados na disciplina 5 se prontificaram a participar dos quatro encontros que aconteceriam ao longo do semestre.

No decurso desses encontros, coletamos dados advindos das discussões a respeito dos quatro relatórios de regência produzidos pelos estagiários do ano anterior e de exposições sobre desenhos, realizados pelos estagiários sujeitos da pesquisa. 
v. 8 (3)

40-62

out-dez 2018

A cada encontro líamos um relatório, a leitura era pausada na medida em que os estagiários, sujeitos da pesquisa, demandavam, a fim de proferirem comentários, reflexões. Os encontros foram gravados em áudio. Os desenhos foram elaborados no final do primeiro encontro, sendo expostos no segundo encontro. Essas exposições também foram gravadas em áudio. O objetivo consistiu em percebermos, a partir das vozes presentificadas nas falas e na exposição dos desenhos produzidos, modos de significar/representar o métier da docência.

\section{O Quadro representacional da profissão docente configurado pelos estagiários}

Para identificarmos as representações sociais sobre a profissão docente sob a ótica dos estagiários, analisamos a recorrência das vozes nos excertos transcritos e entrecruzamos com as representações depreendidas dos desenhos. Os sujeitos desta pesquisa ganharam a designação de S1, S2, S3, S4 e S5. Ressaltamos que S5 só conseguiu participar do último encontro, portanto, não há produção de desenho desse sujeito-pesquisado e suas falas foram menos recorrentes que as dos demais.

Após um encontro de leitura de um relatório e discussão, pedimos aos alunos, no final do primeiro encontro, que desenhassem o que o métier do professor representava para eles. Apresentaremos, primeiramente, a análise das representações construídas nas exposições sobre os desenhos. A seguir, analisaremos alguns excertos relevantes, depreendidos das falas ao longo da leitura dos relatórios, para entendermos modos de representar a profissão docente. 
Desenho produzido por S1
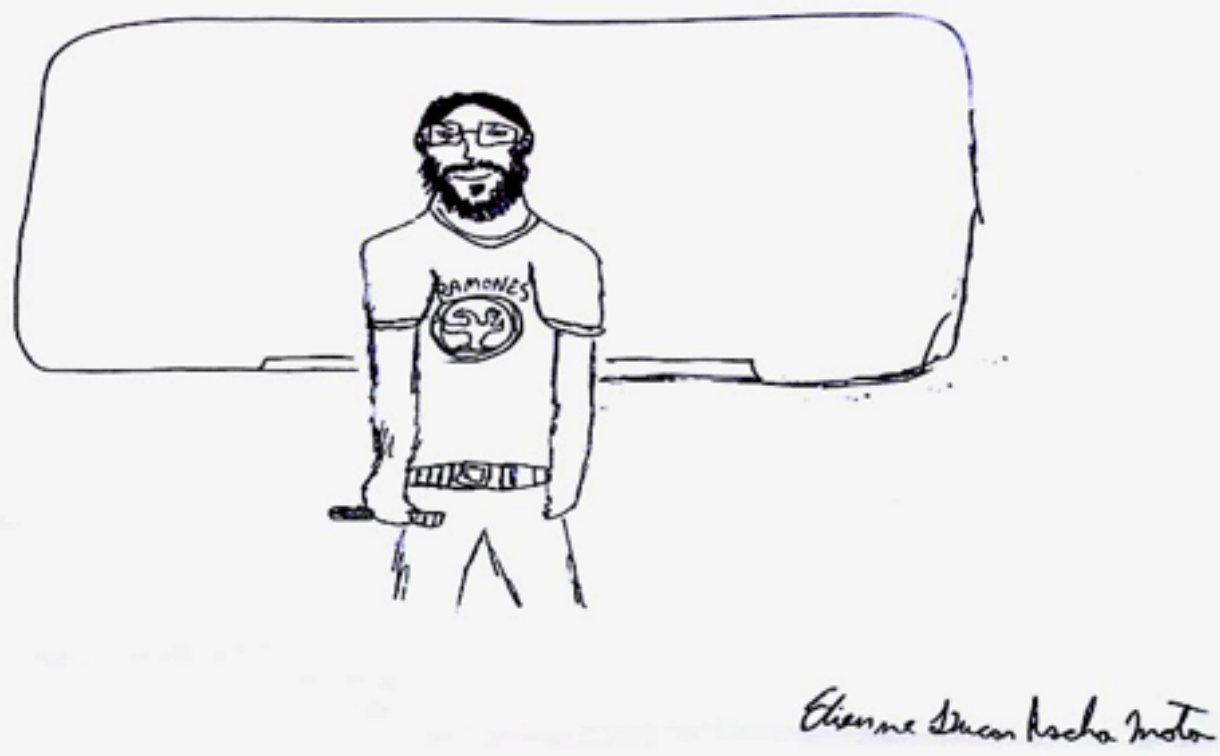

Exposição do desenho produzido por S1 - segundo encontro

S1- Tentei me desenhar, na frente de um quadro em branco, com um pincel na mão, dizendo que, apesar de já ter muito conhecimento teórico, eu não sabia o que colocar ali.

Pesquisadora: Qual o sentimento diante de um quadro em branco?

S1- Sentimento de incompletude tanto da formação, quanto do profissional mesmo (...) eu acho que falta adquirir experiência, porque eu acho que na graduação a gente se forma professor teoricamente, mas na prática não... então... eu acho que será na sala de aula, dando aula diariamente, que a gente realmente se constrói professor.

Pesquisadora: Você acha que nesse momento, depois da experiência do estágio, esse quadro ainda tá em branco?

S1- Tá um pouco preenchido... porque já tive experiência tanto no estágio de Língua Portuguesa, como no de Literatura no semestre passado, inclusive a turma foi muito mais próxima que neste semestre, a turma de agora é mais resistente, não entenderam a ideia do estágio... mas eu acho que faz parte, né?... Vão ter turmas que vão ser mais próximas da gente, outras não... e também serviram para eu perceber que tipo de aula eu queria dar... 
v. 8 (3)

40-62

out-dez

2018

A exposição sobre o desenho de S1 reafirma, nos vários momentos relatados pelos estagiários-pesquisados através das reflexões e, ainda, nos desabafos frequentes de alunos do fim do curso, o quanto se sentem despreparados para aplicarem a bagagem teórica adquirida na graduação, como S1 salienta, forma-se o "professor teoricamente".

Essa representação concernente ao fato de que a academia forma o professor na teoria, de que há uma idealização do que é ensino, do que é escola, da profissão propriamente dita é reiteradamente expressa pelos estagiários-pesquisados.

Nos excertos abaixo, identificamos os dêiticos de pessoa, de forma a compreender como os estagiários se representam na profissão, de maneira individual ou coletiva.

\section{Excerto 01 - segundo encontro}

S4- A gente sabe da dificuldade toda da nossa profissão... a questão salarial... a necessidade de buscar o tempo todo formação...da violência... da precarização das salas de aula... a Universidade idealiza demais a escola e não tematiza... não traz para discussão essas questões sobre o que iremos enfrentar. Saímos despreparados e iludidos.

Excerto 02 - segundo encontro

S2- É um curso de licenciatura... mas há muita teoria... e a gente fica perdida... Eu uso isso tudo como?

S1- Isso mesmo... a prática só aparece nos dois últimos semestres no curso de licenciatura.

S3-Aprática deveria ser mais bem distribuída, talvez ficasse mais impregnada na memória e levasse os alunos a identificarem-se mais com o curso.

Excerto 03- terceiro encontro

S1- Porque, por exemplo, há algumas profissões como Medicina, Direito, que você vai ter aquele salário "bom", estável, até o final de sua carreira e será valorizado socialmente, já o professor não... se ele não buscar se atualizar sempre, até porque está lidando com seres humanos né... o conhecimento muda...ele fica para trás e ele se perde... Então as questões de salário, de condições de trabalho... Há uma série de fatores exteriores a nós que dá muito mais medo, traz a ideia de escuridão, do que propriamente a atividade do professor. Pena é que temos pouco momento para refletir sobre isso na graduação. 
Nota-se que toda a tessitura discursiva está marcada pela presença de dêiticos como "nós" e "a gente" que revelam a existência do que chamamos de voz do coletivo de trabalho, ou seja, uma instância coletiva à qual eles já pertencem, quer seja como "grupo de estagiários" ou como grupo de futuros "professores". Há uma assunção da condição de membro que se vale das representações sobre o métier (baixo salário, estrutura precária de trabalho, desprestígio em relação às outras profissões) que são colocadas como se houvesse um consenso, uma concordância entre os membros. No excerto 03, quando o estagiário S1 fazia a sua exposição, ele sinalizou com as mãos como se houvesse aspas na palavra "bom". Conforme Maingueneau (2002), o uso das aspas é revelador do gerenciamento de vozes e, portanto, traduz o processo de refletir na enunciação (processo de reflexividade) tomadas de posicionamentos. As aspas utilizadas no excerto em questão sugerem que S1 acredita que o salário é relativo ao prestígio ou desprestígio de algumas profissões e que os seus pares partilharão da mesma representação.

Conforme se depreende dos excertos destacados, a voz do coletivo questiona a formação ofertada pela Universidade que não privilegia a prática, a realidade do métier.

Observe que S1, no excerto 03, avalia as dificuldades narradas, que geram medo, como "fatores exteriores" à atividade do professor. O que nos possibilita inferir que essa "atividade do professor", para o estagiário-pesquisado, é o ensino. As outras variáveis de cunho negativo são externas a "nós" e, portanto, à própria atividade.

Sobre a representação de desprestígio da docência, segue uma sequência, envolvendo os sujeitos pesquisados, após o posicionamento de S1, que gerou reflexão sobre o métier. 
v. 8 (3)

40-62

out-dez 2018
Excerto 04 - terceiro encontro

S1- É uma discussão muito complicada de se travar essa da falta de valorização, porque por um lado, você tem o professor como coitadinho, sendo o Estado o vilão, atuando para minar as condições de trabalho e, por outro lado, há quem pense que se o cara tá em uma profissão ruim é porque não se esforçou. Eu não sei, às vezes, como me posicionar... S3- Gente, há problemas como toda profissão, mas há peculiaridades, tanto sobre o quanto a profissão é gratificante, profissão nobre sim, mas com vários entraves... sobretudo no Brasil...

S4- Também temos que ver o tipo de escola, se pública ou privada...

S3- Muita gente pensa que se quer ganhar bem, vai para a iniciativa privada...

S1- Muitos pensam que a iniciativa privada é a salvação...

S4- No governo atual, então, querem deixar o Estado mínimo.

S1- Mas se você for parar para pensar, eles vão fazer, diante da reforma da CLT, da reforma do Ensino Médio, com que os professores da rede pública sofram o que os professores da rede privada já sofrem. O professor é um profissional o tempo todo ameaçado. Na escola privada, os professores ficam totalmente sem autonomia, o pessoal do ensino público sempre gozou dessa liberdade de planejar e ministrar aula, diferentemente, da escola privada. Eu já tive experiência com os dois lados, prefiro atuar mil vezes no setor público.

S3- Acho que é uma questão de luta de classes, do grupo se unir e pressionar, só se melhora algo se todos lutarem pelo mesmo fim. Somos muito desunidos!

Através da interação, promovida pela leitura de uma parte do relatório em que houve a tematização da desvalorização do magistério, os estagiários-pesquisados manifestaram interesse em discutir um pouco mais sobre a questão. Como se nota, a representação de desprestígio do magistério é mobilizada e acaba por instaurar reflexões sobre a (re)ação do professor diante da imagem social que se constrói a respeito dele. S1 expõe duas possibilidades de retratar a figura do professor face à desvalorização profissional: ou ele é visto como "coitadinho" (com a atribuição de culpa ao Estado) ou como aquele que não se esforçou o suficiente para ter outra profissão. Essa assertiva denota que a questão da vocação não se apresenta como mote para se tornar professor. 
S3, ainda que de maneira mobilizada, expõe o lado positivo da docência (profissão gratificante, profissão nobre). A modalização ocorre com a relativização do tom positivo quando há menção da sequência "mas com vários entraves... sobretudo, no Brasil". S4 introduz a diferença entre a docência no setor público e no setor privado, a reflexão sobre a diferença se dá em torno da variável autonomia, sendo o setor público visto como melhor para trabalhar nesse quesito. A propósito, vale destacar que o Estado novamente é colocado em oposição à profissão, ao ter a intenção, segundo os estagiários pesquisados, de precarizar a docência através da reforma trabalhista e do ensino médio.

Por fim, S1, na condição de membro, demonstra a importância da coletividade para a promoção de mudanças profissionais, valendo-se da representação de que o professor é uma classe desunida.

Nessa sequência, percebemos a recorrência do que aqui iremos denominar voz do senso comum, marcada pelas expressões: há quem pense que, muitos pensam que, muita gente pensa que. As exposições, sejam para confirmar os posicionamentos tomados, sejam para refutar, operam com vozes reiteradas socialmente sobre a docência (profissão nobre, setor público melhor que privado ou vice-versa, classe desunida). Segundo Bakhtin (2003), essas vozes instauram "o fundo necessário para a sua voz, fora do qual são imperceptíveis, 'não ressoam' os seus matizes" (BAKHTIN, 2003, p. 88).

Passemos, então, para o desenho e exposição de S2.

Desenho produzido por S2

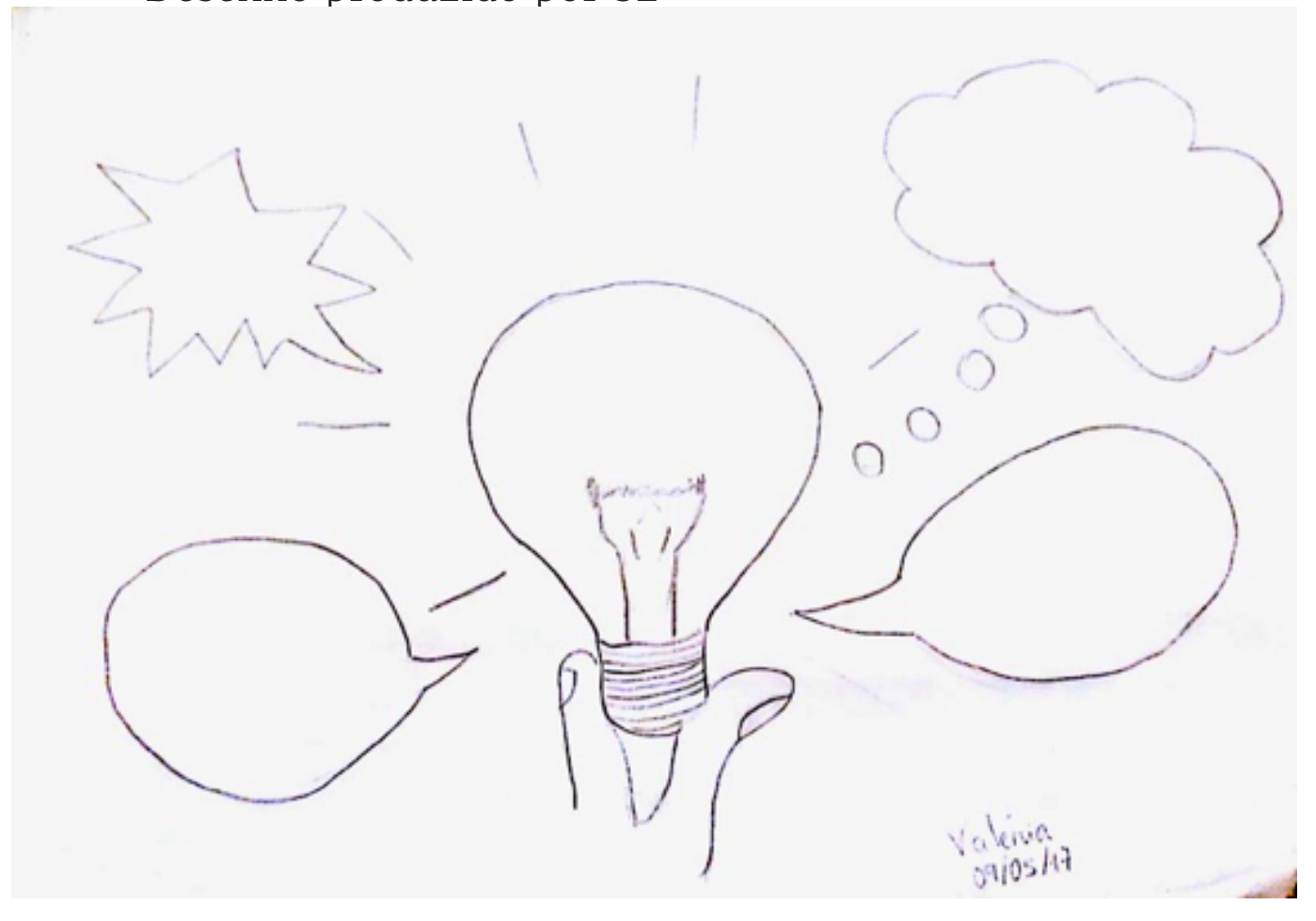


v. 8 (3)

40-62

out-dez 2018
Exposição do desenho produzido por S2 - segundo encontro S2- Quando eu pensei nesse desenho foi mais no sentido de discutir ideias, porque eu tenho que saber da realidade deles um pouco, para poder montar o que eu quero expor, construir o conhecimento deles com o meu.

S3: O professor seria a Lâmpada?

S2-A ideia trabalhada em sala que seria a lâmpada, não acho que o aluno é esse ser apagado sem luz, sem conhecimento, o professor deve ser o mediador do conhecimento.

Pesquisadora: Mas por que os balões partem da lâmpada?

S2-Porque seriam as trocas de todos na construção do conhecimento.

A metáfora da lâmpada remetendo ao conhecimento é bastante recorrente nas práticas sociais, sobretudo, no domínio educacional. Quando S2 apresentou o desenho sem a explicação, havia uma expectativa por parte dos ouvintes de que a lâmpada em questão seria a figura do professor representada, como podemos depreender da pergunta de S3 - "O professor seria a lâmpada?" - Mas, em seguida, S2 defendeu a ideia de que a lâmpada seria a representação do próprio conhecimento, o objeto de ensino. A expectativa dos demais, calcada na representação "aluno ser sem luz", fez com que ela se opusesse a tal representação "não acho que o aluno é esse ser apagado sem luz, sem conhecimento". O professor, para S2, deverá ser mediador desse conhecimento, sendo os balões a representação das trocas necessárias para o processo de aprendizagem.

Sobre a representação do professor construída pelos alunos, sobretudo, quando é o estagiário nesse lugar, há um relato que merece ser exposto para refletirmos. 
Excerto 05 - quarto encontro

S3- Medo mesmo eu não tinha mais, por causa da minha experiência com a língua estrangeira, mas a primeira vez na turma de certo modo... são regras novas, não há garantias e a gente não sabe como eles vão se comportar, se irão aceitar...têm turmas que você entra e estão altamente abertas para o novo, o que ele vai trazer de novo... o seu jeito novo né... e têm turmas que vão preparadas para rechaçar, pelo menos essa é a sensação que eu tive de algumas... eles pensam... vamos ficar quietos... no primeiro dizer... a gente castra o professor. Pesquisadora: Mas você percebeu no olhar dos alunos um reconhecimento de você como professor?

S3- Sim. Em geral, sim. Acho que tive esse reconhecimento, eu tive a impressão que mesmo os que rechaçavam, não era a turma toda, mas um pequeno grupo, um ou outro perdido na turma, me pareceu algo de testar. Ele é professor... mas é estagiário... vamos ver até que ponto, ele consegue levar... acho que era isso. Foi a impressão que tive... mas os outros sim, eles me respeitavam como professor e mesmo os que não estavam a fim da aula ou não tinham gostado da metodologia, ficavam quietos e me tratavam com certo respeito.

S3 se vale também da voz da experiência para balizar as suas escolhas e impressões. De certa forma, ainda que se exponha a imprevisibilidade quando se está em uma turma nova, tal constatação colabora para acentuar o que se conhece sobre o métier, porque já se fez o estágio em língua estrangeira.

Vale ressaltar que S3, enunciando em primeira pessoa, expõe a dificuldade do entrelugar professor e estagiário, demonstra as emoções sobre como lidar com a turma no início da experiência, o cenário narrado nos parece uma tensão entre os alunos e o professor/estagiário, nessa tensão há testes, julgamentos, o estagiário e futuro professor se sente ameaçado, a sua capacidade é colocada em xeque, mas, de todo modo, julga ter conseguido ser reconhecido como professor pela maior parte da turma. Isso pode ser observado pelo uso de dêiticos de pessoa e do discurso direto. Observemos, por exemplo, as duas ocorrências de "a gente". Na primeira, temos o estagiário e futuro professor, o que se repete no "você" a seguir. Na segunda ocorrência, "a gente" refere-se ao aluno, ilustrando totalmente o entrelugar ocupado pelo estagiário. Finalmente, no enunciado: "Ele é professor... mas é estagiário... vamos ver até que ponto, ele consegue levar... acho que era isso", vemos 
V. 8 (3)

40-62

out-dez 2018

que se trata da voz do aluno, uma imitação, em discurso direto livre (MAINGUENEAU, 1996), do que o aluno teria dito ou pensado. Nesses exemplos, percebemos a dificuldade de legitimar-se como professor quando se está na posição de estagiário, pois, ainda que os alunos contrários aos estagiários sejam minoria, não é fácil, para quem está iniciando a profissão, ignorar os discursos dissonantes.

Passemos, agora, para a análise do desenho de S3.

Desenho produzido por S3 
Exposição do desenho produzido por S3

S3- O meu desenho seria uma pessoa regando a plantinha, sendo que a pessoa seria o professor e a plantinha o aluno. O professor tem que dar suporte para o crescimento desse aluno, crescimento pessoal, como cidadão e também profissional, porque ele já está no lugar certo, a plantinha tá na terra e o aluno na escola. O professor, então vai guiar e facilitar para que venha a crescer e se desenvolver da maneira correta. Pesquisadora: Se a gente for pensar em termos de planta e fazendo essa analogia com o aluno... a planta não sobreviveria sem esse regar, sem esse cuidado da figura que você coloca no desenho e você acha que o mesmo acontece na escola?

S3- Sim, porque por mais que digam os clichês, a escola é só para transmitir conhecimento ou eu sou só professor, não sou obrigado a educar, quem educa é pai e mãe... eu acho que é um conjunto e eu acho que o que falta... ninguém consegue obrigar pai e mãe a seguir tudo o que a gente aprende na pedagogia, psicologia, enfim... de formação de uma criança, então, a escola tem sim uma responsabilidade, o professor tem sim uma responsabilidade de preencher aquelas lacunas que faltam em casa e se um aluno não tiver isso... tudo bem... ele vai continuar vivendo, mas como? Como ele vai se sustentar? Que tipo de ser humano ele vai ser? Que valores ele vai carregar para essa vida? Que caminhos ele vai seguir? Talvez não sejam os melhores...

A analogia de se comparar a docência com o ato de regar a planta, cuidar, adubar é extremamente constante quando se analisa o discurso docente. Por isso, consideramos que se trata da voz do senso comum, por veicular algo que faz parte das representações construídas socialmente, em diferentes contextos, acerca do trabalho do professor. De certa forma, um dos efeitos de sentido que se tem quando o professor é o responsável por fazer o aluno desenvolver, assim como o cultivador da planta, é de uma relação de dependência. O professor é representado como vital, imprescindível para o desenvolvimento e sobrevivência do aluno. Representação essa confirmada na exposição do desenho, quando S3 afirma que apesar de pouco valorizado, até rejeitado pela sociedade, é "sem sombra de dúvidas muito importante". Há uma hiperbolização da importância do professor na sociedade, quando se compara o professor ao agricultor, cultivador etc. Ele ganha status de criador, algo romantizado, figura que se torna condição sine qua non para a existência de outro ser social, neste caso, do aluno. 
V. 8 (3)

40-62

out-dez 2018

A voz do senso comum, configurada aqui pelo intercâmbio de traços de duas profissões - agricultor e professor -, colabora para a construção argumentativa de tornar o professor figura imprescindível para a prática formativa.

Passemos agora para a análise do último desenho.

Desenho produzido por S4

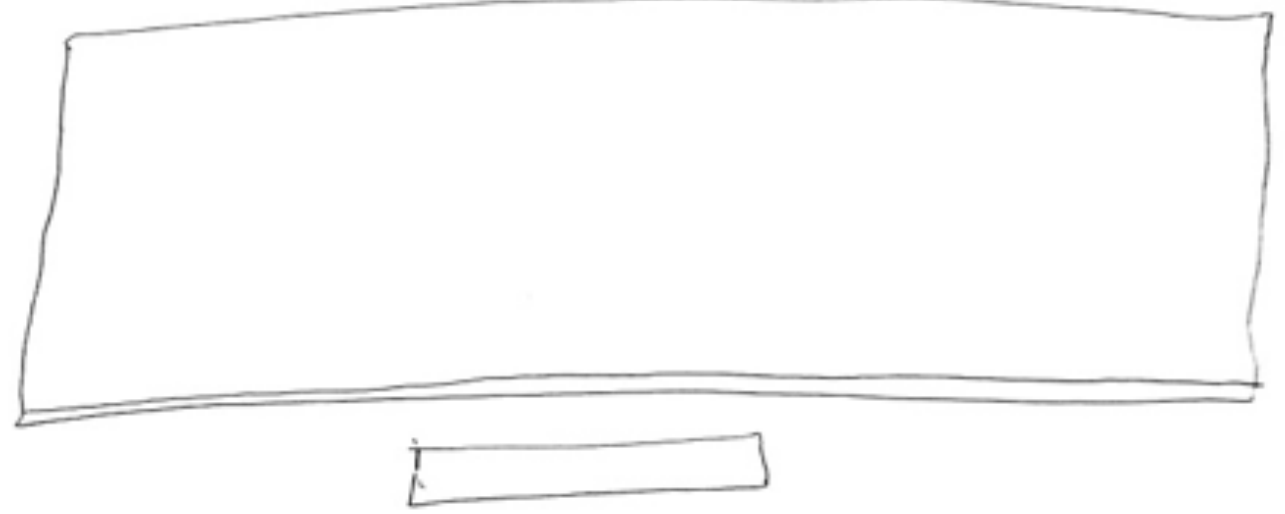

58
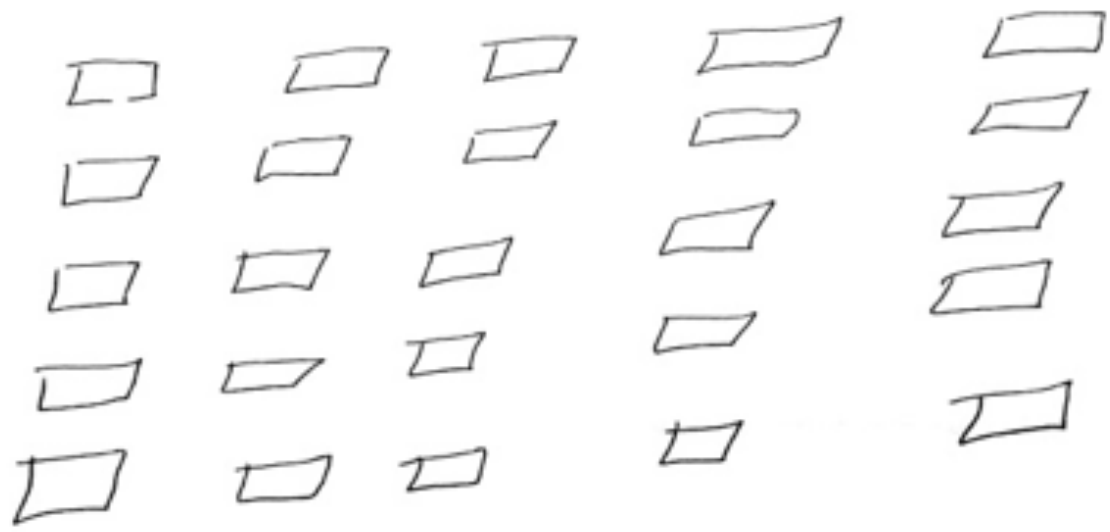
Exposição do desenho produzido por $\mathrm{S} 4$

S4- Eu desenhei a sala de aula, a lousa, o professor no meio e os alunos. Eu coloquei, porque acho que tem que ter um mínimo de disciplina. Hoje a gente tem salas de sessenta alunos, fica muito difícil de trabalhar... é um absurdo. Deveria ter no máximo uns trinta alunos para que realmente tenha um rendimento bom... eu digo pensando no Colégio XXX... são turmas pequenas, organizadas por faixa etária, seguem a disciplina e desenvolvem muito bem. o professor tem condição de conhecer os alunos... com sessenta... não há condição, gera trauma na gente.

Pesquisadora- Esse espaço sala de aula, você manteria como professor? S4- Eu reconheço essa organização até aqui na universidade, até nas aulas de filosofia eram assim... Aqui na universidade quando é prova... exigem desse mesmo jeito.

Pesquisadora: São representações sobre sala de aula que a gente tem... essa é a mais clássica...

S4- Sim essa é a mais tradicional. Quando é prova é do mesmo jeitinho. S3- Há professor aqui que mantém o círculo, mas pede para a gente se afastar mais.

S4 denuncia o que de fato é comum na realidade escolar do nosso país, sobretudo, nas escolas públicas, qual seja: o excesso de alunos no âmbito da sala de aula. Esse problema é apontado por ele como dificultador do trabalho do professor, ele menciona inclusive a palavra trauma, ao narrar sua experiência quando se deparou com sessenta alunos na sala de aula. Esse fato também serviu de argumento para justificar a organização da sala desenhada. Para S4, essa maneira de organizar a sala é a melhor para conter a indisciplina e conseguir êxito na atividade a ser desenvolvida, tendo em vista o quantitativo excessivo dos alunos.

No seu projeto comunicativo, S4 recorre à voz teórica quando avalia a organização tradicional da sala (representação canônica sobre a sala de aula), o estagiário-pesquisado menciona que até na universidade, eles se deparam com essa organização (voz acadêmica). Particularmente, em momentos de avaliações, os professores solicitam essa organização ou, ao menos, que os alunos sentem de maneira afastada.

Após o fim da leitura do último relatório, a pesquisadora questionou sobre o porvir aos estagiários-pesquisados, exporemos a sequência para, em seguida, refletirmos. 
v. 8 (3)

40-62

out-dez 2018

\section{Excerto 07}

Pesquisadora- O que imaginam para vocês como profissionais?

S3 - Tenho grandes expectativas... estou até bem empolgado com isso... tentar me desafiar diante de perfis diferentes de alunos, mas falando da nossa sociedade particularmente, eu temo um bocado o futuro da profissão, porque até pouco tempo já era complicado, a gente já tinha clichês de professor é pobre, é o coitado...com as últimas medidas desse governo, vieram não só a legitimar os clichês negativos, mas também a oficializá-los. De um modo mais amplo, eu tenho muito medo, mas numa microperspectiva, eu como professor, a escola, os colegas... eu tenho uma perspectiva bem positiva. Ainda.

S1- Eu me vejo como professor até o fim da vida, eu penso no ensino público mesmo, talvez na universidade, pós-graduação... não sei... apesar das experiências do estágio, todas serviram para eu me apaixonar ainda mais. Eu gostei de dar aula, eu gostei da sensação de tá lá na frente, de tá puxando o contato com os alunos, eu realmente me encontrei como profissional da educação.

S5- Eu vou terminar o curso esse ano, vou me preparar para tentar a pós... é uma coisa que quero fazer, mas este ano eu quero trabalhar, eu quero trabalhar como professor, não sei se vou conseguir... Eu queria muito trabalhar na escola pública, sobretudo, no ensino médio, agora, se eu for para a particular... seria para sobreviver.

S1- É um absurdo o que estão fazendo com a educação... é um imperialismo isso... não quero entrar em questões políticas, mas estão obrigando os professores virem para as escolas privadas, sucateando o setor público. S2- Como todos já disseram, eu vou continuar como professora, não sei se irei aguentar por muito tempo, digo pelas experiências que eu tive nas escolas, agressões dos alunos, tem professor que se acostuma com isso... Esse tipo de coisa que eu não sei se irei aguentar. Não é normal, por exemplo, dois meninos se socarem na sala e ninguém fazer nada.

Como é possível observar, a voz do senso comum a respeito da figura docente é colocada para contestar a imagem construída pela sociedade na atualidade sobre o professor, ora para ajudá-los a constituir o sentimento de pertença, há sempre um movimento plástico de convergência e divergência face ao acervo representacional. Fato é que ainda que de maneira bastante modalizada, com certo cuidado com o discurso para serem bem realistas, com apontamentos de problemas diversos, desafios, há um sentimento final de esperança, de otimismo e de aposta na profissão. Todos disseram que querem ser professores, posicionam-se como membros de uma categoria tão pouco valorizada socialmente. 
A falta de valorização social, o desprestígio do métier é o que mais se reconhece no discurso dos estagiários-pesquisados, seja quando se colocam na condição de estagiários, seja na condição de professores ou quando tematizam o magistério de um modo geral. O Estado (sistema educacional, órgãos oficiais, governo) é sempre colocado como adversário, aquele que piora a condição do professor, que precariza o seu trabalho. O Estágio traduz uma mistura de sentimentos de receio, temor, incompletude, mas, concomitantemente, há esperança de que se realizem profissionalmente.

\section{Considerações Finais}

Os encontros com os estagiários/futuros professores, circunscritos pela leitura dos relatórios de estágio, foram profícuos para a reflexão sobre a docência a partir do processo dialógico do falar de si e do(s) outro(s). Através da mobilização de vozes presentificadas no discurso do estagiário (voz do métier, voz do senso comum, voz da universidade, etc), reconhecemos representações que colaboram para a significação do futuro métier, que devem ser tematizadas na formação inicial a fim de promovermos reflexão sobre questões, expectativas, sentimentos relacionados à docência.

O discurso (re)constituído, objetivado, mobiliza representações que nos permitem reconhecer um pouco melhor o profissional que queremos/devemos formar. Clot (2010, p. 147) vem corroborar para essa assertiva quando propõe que se deve "não só compreender para transformar, mas também transformar para compreender". Os diálogos instaurados para refletir sobre o trabalho tornam-se momentos produtivos para atualizar representações, ressignificar o agir e trocar experiências e sentimentos. O outro, pensado aqui na condição de membro, colabora para reconfigurações de modos de agir, de pensar, de sentir a docência.

A compreensão, fomentada pelo diálogo, proporciona um novo contexto, que se desenha a partir do encontro com o passado, reinterpretando-o, reavaliando-o. Trata-se, pois, de uma metamorfose do passado (CLOT, 2010, p. 147), a partir de elementos do presente (representações sobre o trabalho construídas nos textos). Em nosso entender, essa (trans)formação poderá impactar nas escolhas do estagiário/ futuro professor quando efetivamente estiver exercendo a docência.

Defendemos, portanto, instaurar momentos que oportunizam discussões sobre o métier, nas quais os estagiários/futuros professores possam mobilizar diversas vozes para que se inscrevam na condição de membro e, gradualmente, se (trans)formem nessas interações. 
v. 8 (3)

40-62

out-dez 2018

\section{Referências}

AUTHIER-REVUZ, J. Heterogeneidade(s) enunciativa(s). In: Cadernos de estudos linguísticos. Trad. de Celene M. Cruz e João W. Geraldi. Campinas, São Paulo: 1990. p. 25-42.

BAKHTIN, M. Os gêneros do discurso: enunciado, unidade da comunicação verbal. In: Estética da criação verbal. Tradução de Maria Ermentina Galvão Pereira. São Paulo: Martins Fontes, 2003.

BAKHTIN, M./VOLOSHINOV, V. Marxismo e filosofia da linguagem. São Paulo: Hucitec, 2004.

BÉGIN, P. \& CLOT, Y. L'action située dans le développement de l'activité. Activités, v. 1, n. 2, p. 27-49, 2004.

BOCH, F.; GROSSMANN, F. Referir-se ao discurso do outro: alguns elementos de comparação entre especialistas e principiantes. Revista Scripta, Belo Horizonte, v. 6, n. 11, p. 97-108, 2002.

CLOT, Y. La fonction psychologique du travail. Paris: PUF, 1999.

Trabalho e poder de agir. Tradução de Guilherme João Freitas Teixeira e Marlene Machado Zica Vianna. Belo Horizonte: FabreFactum, 2010.

CLOT, Y.; FAITA, D. Genres et styles en analyse du travail: concepts et méthodes. Travailler, 4 ed., 2000. p. 7-42.

GARCÍA, M. C. Formação de professores para uma mudança educativa. Porto: Porto Editora, 1999.

JODELET, D. Représentations sociales: un domaine en expansion. In : JODELET, D. (orgs.). Les Représentations Sociales. Paris: Press Universitaires de France, 1989.

MACHADO, A. R. o ensino como trabalho: uma abordagem discursiva. Londrina: Eduel, 2004.

MAINGUENEAU, D. Análise de Textos de Comunicação. Trad. de Cecília P. de Souza-e-Silva, Décio Rocha. São Paulo: Cortez, 1996.

MOSCOVICI, S. Des représentations collectives aux représentations sociales. In : JODELET, Denise (Org.). Les représentations sociales. Paris: Press Universitaires de France, 1989.

SAUJAT, F. Comme les enseignants débutants entrent dans le métier. Disponível em: <http://revuedeshep.ch/pdf/vol-1/2004-1-saujat.pdf>. Acesso em : 05 mai. 2018. 